\title{
The potential of stomata analysis in conifers to estimate presence of conifer trees: examples from the Alps
}

\author{
Brigitta Ammann • Willem O. van der Knaap • Gerhard Lang • \\ Marie-José Gaillard • Petra Kaltenrieder • Manfred Rösch • \\ Walter Finsinger $\cdot$ Herbert E. Wright $\cdot$ Willy Tinner
}

Received: 20 July 2013/Accepted: 5 January 2014

(c) Springer-Verlag Berlin Heidelberg 2014

\begin{abstract}
To estimate whether or not a plant taxon found in the fossil record was locally present may be difficult if only pollen is analyzed. Plant macrofossils, in contrast, provide a clear indication of a taxon's local presence, although in some lake sediments or peats, macrofossils may be rare or degraded. For conifers, the stomata found on pollen slides are derived from needles and thus provide a valuable proxy for local presence and they can be identified to genus level. From previously published studies, a transect across the Alps based on 13 sites is presented. For basal samples in sandy silt above the till with high pollen values of Pinus, for example, we may
\end{abstract}

Communicated by A. E. Bjune.

B. Ammann $(\varangle)$. W. O. van der Knaap · P. Kaltenrieder ·

W. Tinner

Institute of Plant Sciences and Oeschger Centre for Climate

Change Research, University of Bern, Altenbergrain 21,

3013 Bern, Switzerland

e-mail: Brigitta.Ammann@ips.unibe.ch

G. Lang

Stresemannstr. 28, 88400 Biberach an der Riß, Germany

M.-J. Gaillard

Department of Biology and Environmental Science, Linnaeus

University, 39182 Kalmar, Sweden

M. Rösch

Landesamt für Denkmalpflege, Fischersteig 9,

78343 Hemmenhofen, Germany

W. Finsinger

Centre for Bioarchaeology and Ecology (CBAE - UMR 5059

CNRS/EPHE/UM2), Institut de Botanique, 34090 Montpellier, France

H. E. Wright

Limnological Research Center, University of Minnesota,

310 Pillsbury Drive SE, Minneapolis, MN 55455, USA distinguish pine pollen from distant sources (samples with no stomata), from reworked pollen (samples with stomata present). The first apparent local presence of most conifer genera based on stomata often but not always occurs together with the phase of rapid pollen increase (rational limit). An exception is Larix, with its annual deposition of needles and heavy poorly dispersed pollen, for it often shows the first stomata earlier, at the empirical pollen limit. The decline and potential local extinction of a conifer can sometimes be shown in the stomata record. The decline may have been caused by climatic change, competition, or human impact. In situations where conifers form the timberline, the stomata record may indicate timberline fluctuations. In the discussion of immigration or migration of taxa we advocate the use of the cautious term "apparent local presence" to include some uncertainties. Absence of a taxon is impossible to prove.

Keywords Stomata Conifers $\cdot$ Presence-absence of plant taxa $\cdot$ Apparent local presence $\cdot$ European Alps

\section{Introduction}

While palynology is considered the most reliable tool for reconstructing the vegetation history of a site, records of plant macrofossils such as needles, fruits, bud-scales and periderm are by far the best indicators of the local presence of any plant taxon in the past (Barnekow 1999; Birks 1973, 1984, 2001, 2007; Birks and Birks 1980, 2000, 2003; Birks and Mathewes 1978; Dunwiddie 1987; Eide et al. 2006). However, at many study sites sedimentary macrofossil concentrations are too low to be useful for reconstruction of the vegetation history. Conifer stomata are directly derived from conifer needles and thus are a very valuable proxy for local presence of conifers. Their identification on 
pollen slides may serve as a substitute for a thorough macrofossil analysis, especially where macrofossils have been degraded through transport, biotic or sedimentary processes such as fragmentation, decomposition, oxidation or corrosion. In a pioneer study Trautmann (1953) showed that the stomata of European conifers found on pollen slides could be identified to genus. Subsequently a few pollen studies in Europe included records of conifer stomata (Jensen et al. 2002; Froyd 2005; Bjune et al. 2004; Paus et al. 2011), though the method is still far from being regularly applied by palynologists. Keys for North American and northern Eurasian conifer stomata show that the morphological differences discovered in Europe can be applied to other floristic regions in which conifers are abundant in the vegetation (Hansen 1995; MacDonald 2001; Sweeney 2004). As in Europe, the taxonomic resolution usually reaches only the genus level, which is comparable to pollen, but lower than for macrofossils (Birks and Birks 2000; Birks 2001, 2007; Tinner and Theurillat 2003). In Pinus, however, recent attempts suggest that stomata of Diploxylon and Haploxylon types could possibly be separated (see supplementary material in Magyari et al. 2012). The preservation of stomata has not been tested experimentally, but Lang (2005) reported that, based on a suggestion by Helmut Müller, pollen preparation without acetolysis can be used to make sure that stomata are not additionally degraded.

In this study we address the question to what degree and under which conditions we can use the stomata record of conifers to assess the presence of a taxon, keeping in mind that the absence of a taxon cannot be unambiguously proven (Birks and Birks 2003; Tinner and Theurillat 2003; Leitner and Gajewski 2004; Hicks 2006; Tinner and Lotter 2006; Eide et al. 2006; Giesecke 2013). Under the presence-absence problem we understand the difficulties in proving the presence or absence of taxa on the basis of fossil records. This issue has been at the centre of debate since the earliest days of palynology (Welten 1944; Firbas 1949; Lang 1992, 1994; Tinner and Lotter 2006).

In order to distinguish presence from local absence of conifers, the modern relationship between pollen and stomata across long transects at the polar tree line has been studied by Hansen et al. (1996), Pisaric et al. (2000, 2001) and Leitner and Gajewski (2004) and has been applied to the Holocene record (Clayden et al. 1996, 1997; Pisaric et al. 2003; Leitner and Gajewski 2004; Bjune et al. 2004). Threshold values for pollen indicating local presence of plant populations might be derived if compared with the stomata record; these thresholds were often lower than expected, for example $>1 \%$ for Tsuga canadensis in Wisconsin (Parshall 2002). Froyd (2005) demonstrates with a two-step method of counting Pinus stomata in
Scotland, first by using standard counts and second by using about four times higher resolution. With such refined analysis the first stomata may be found when only $1.0 \%$ of the pollen is from Pinus, a limit also shown in accumulation rates of pollen and stomata. $1.0 \%$ is far below what is usually assumed to be evidence of local presence of Pinus, making the first occurrence at the Scottish site up to 1,600 years earlier. Lacourse et al. (2012) also come to the conclusion that stomata of three conifer taxa may indicate local presence hundreds to thousands of years before conventionally used pollen percentage thresholds are reached. Obviously pollen percentage thresholds are a difficult concept because not only is there the problem of closed data, but they are hardly ever calibrated, in contrast to pollen influx or to plant macroremains, for which an attempt is presented by Pidek et al. (2013).

An important refinement for the presence-absence problem can be achieved with the inclusion of plant macrofossil analysis. Birks et al. (1996) provide a review with emphasis on northern Europe; Wick and Tinner (1997) show the convincing parallelism in Holocene records of pollen, stomata and macrofossils as concentrations for Pinus cembra and Larix decidua at timberlines (upper limit of forests) in the central and southern Alps. For the southern Carpathians Magyari et al. (2012) show with records of pollen, stomata and plant macrofossils how the vegetation and the tree line changed during the Late-glacial and early Holocene. In Ontario, Yu (1997) used stomata and macrofossils to separate two genera that are hard to distinguish by pollen morphology, namely Juniperus and Thuja.

After discussing the stomata evidence in the central Alps, we examine the relevance of the presence-absence problem for interpretations of vegetation history. Particularly, we address problems related to the reconstruction of the date of immigration of a taxon, migration processes in time and space, and population establishment and expansion (Wick and Tinner 1997; Tinner and Theurillat 2003; Eide et al. 2006). The presence-absence verification may also help to address important issues such as taxa extinctions. To do this we compare selected sites that have both pollen and stomata and partly also macrofossil records. All sites have been previously published, and the references allow more detail to be gained about the original methodologies and interpretations. Most of the sites analyzed are from the Bern school (Welten 1982a, b; Ammann and Wick 1993; Wick and Tinner 1997 and references in Table 1). This guarantees homogeneous identifications of pollen, spores, stomata and macrofossils.

Our contribution assembles stomata and pollen records from alpine and circum-alpine sites and discusses the 


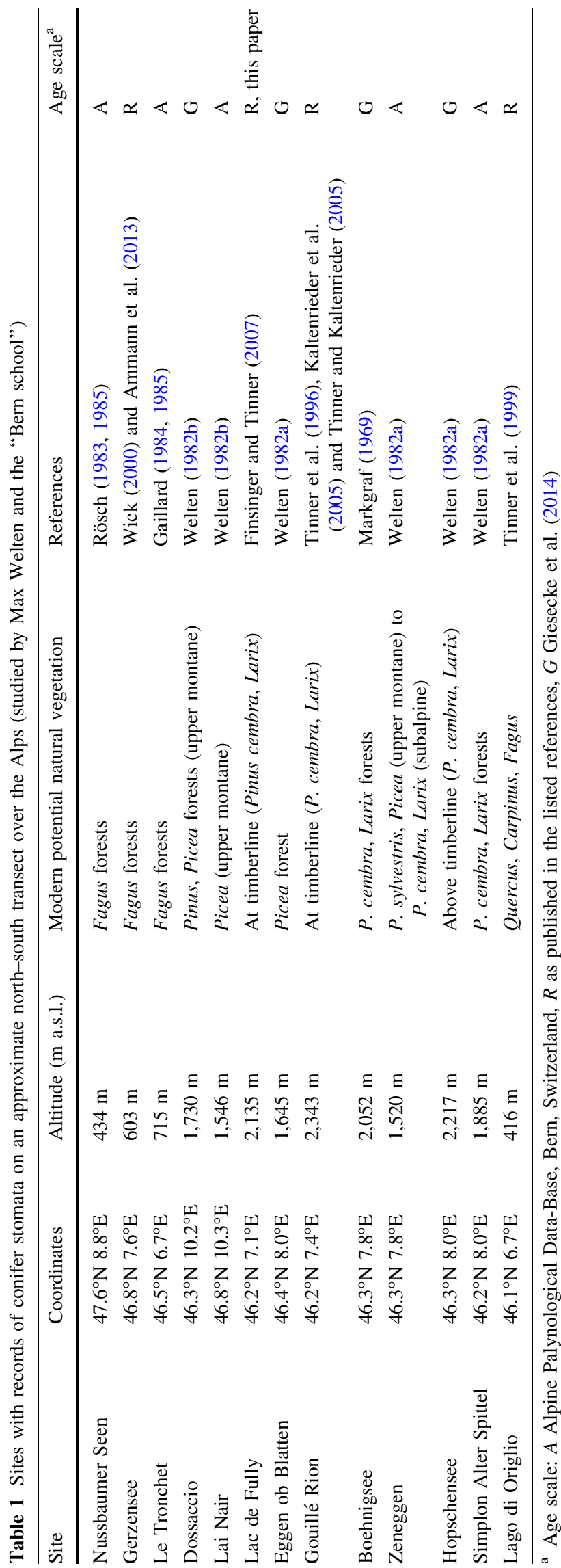

"presence-absence problem" for questions about the arrival and migration of conifer taxa, population dynamics and fluctuations of timberline. These issues may contribute not only to a better understanding of past vegetational dynamics, but they may also help to refine our understanding of potential future vegetational responses to global climatic warming.

\section{Materials and methods}

In order to estimate the apparent local presence of conifers, we selected published sites with data on pollen and stomata on an approximate south-north transect across the Alps (Fig. 1). Out of the five genera Juniperus (juniper), Larix (larch), Pinus (pine), Picea (spruce) and Abies (fir), three have only one species each native to the study region ( $L$. decidua, Picea abies, Abies alba), while for juniper and pine we elaborate this issue in the section below on 'Stomata and pollen across the Alps'. For simplicity, we use genus names where no confusion among species is possible. We also include macrofossils where available (Gouillé Rion, Lac Supérieur de Fully, hereafter called Lac de Fully). Pollen data, including stomata as well as macrofossils, are extracted from the Alpine Palynological Database, which is run by University of Bern. The time scales are according to the original publications or to Giesecke et al. (2014), as listed in Table 1; all ages are expressed in cal. B.P. (calibrated years before A.D. 1950). Further methodological details are available in the original publications (Welten 1982a, b; Markgraf 1969; Rösch 1983, 1985; Gaillard 1984, 1985; Tinner et al. 1996, 1999; Wick 2000; Kaltenrieder et al. 2005; Tinner and Kaltenrieder 2005; Finsinger and Tinner 2007; Ammann et al. 2013).

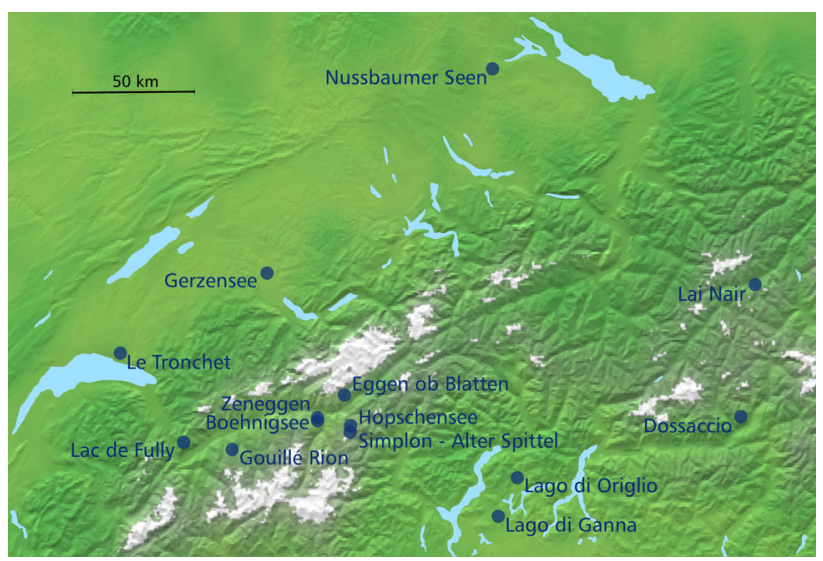

Fig. 1 Maps of the discussed sites 
Fig. 2 Modern altitudinal distribution of Pinaceae taxa from the Swiss lowlands across the Alps, and the position of the palaeoecological sites. Larix decidua in the lowlands was planted for forestry purposes. Black horizontal bars indicate the median value of altitude, dark grey $50 \%$, light grey $90 \%$ and white $100 \%$. L lowlands, $P$ pre-alps, $C$ central Alps, $S$ southern Alps; modified from Brändli (1998)
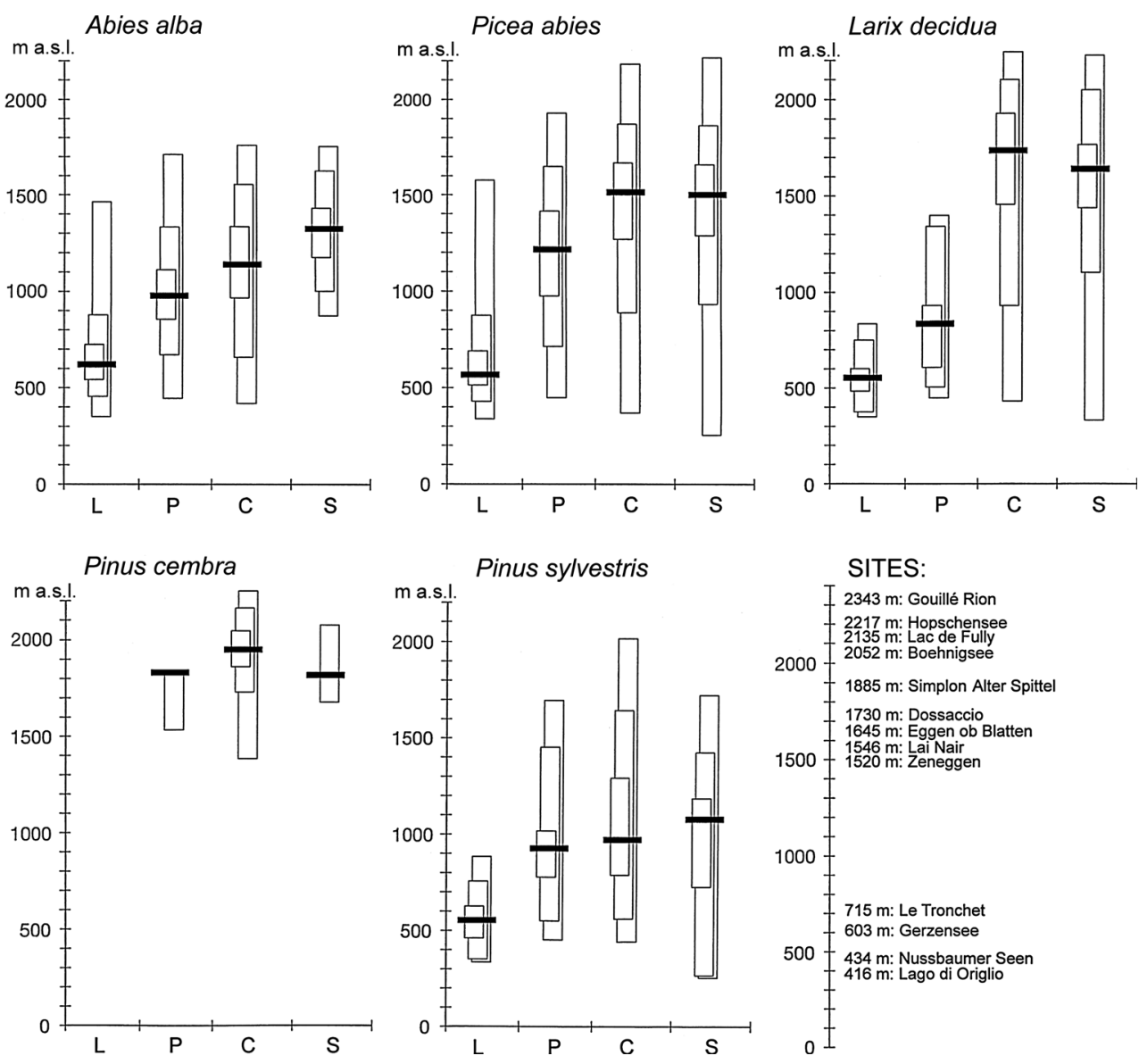

found, pointing to the sporadic local presence of the species. The relationships to various aspects of climatic change are discussed in Tinner et al. (1996), Kaltenrieder et al. (2005) and Tinner and Kaltenrieder (2005). During the Bronze Age (4,150-2,750 cal. B.P.), pollen, macrofossils and stomata of $P$. cembra declined rapidly-early transhumance is indicated by the evidence for burning of trees by humans for summer farming (Tinner et al. 1996; Kaltenrieder et al. 2005; Colombaroli et al. 2010).

Lac de Fully

Two medium-size lakes are situated in a former glacial cirque above the village of Fully in lower Valais. The sediments of the upper of the two lakes (Lac Supérieur de Fully, at 2,135 m a.s.1.) were analysed for pollen, stomata and plant macrofossils (Finsinger and Tinner 2007). The lake now has a surface of ca. 25 ha, but it has had an artificial dam there since A.D. 1914. The lake is below the natural tree line (here about at 2,200-2,400 $\mathrm{m}$ a.s.1.), but today its catchment is mostly treeless and is used for summer farming. The vegetation during the early to midHolocene was first an open forest with $D$. octopetala, tree Betula and J. nana, which changed at about 8,200 cal. 
Gouillé Rion, 2343 m a.s.I.

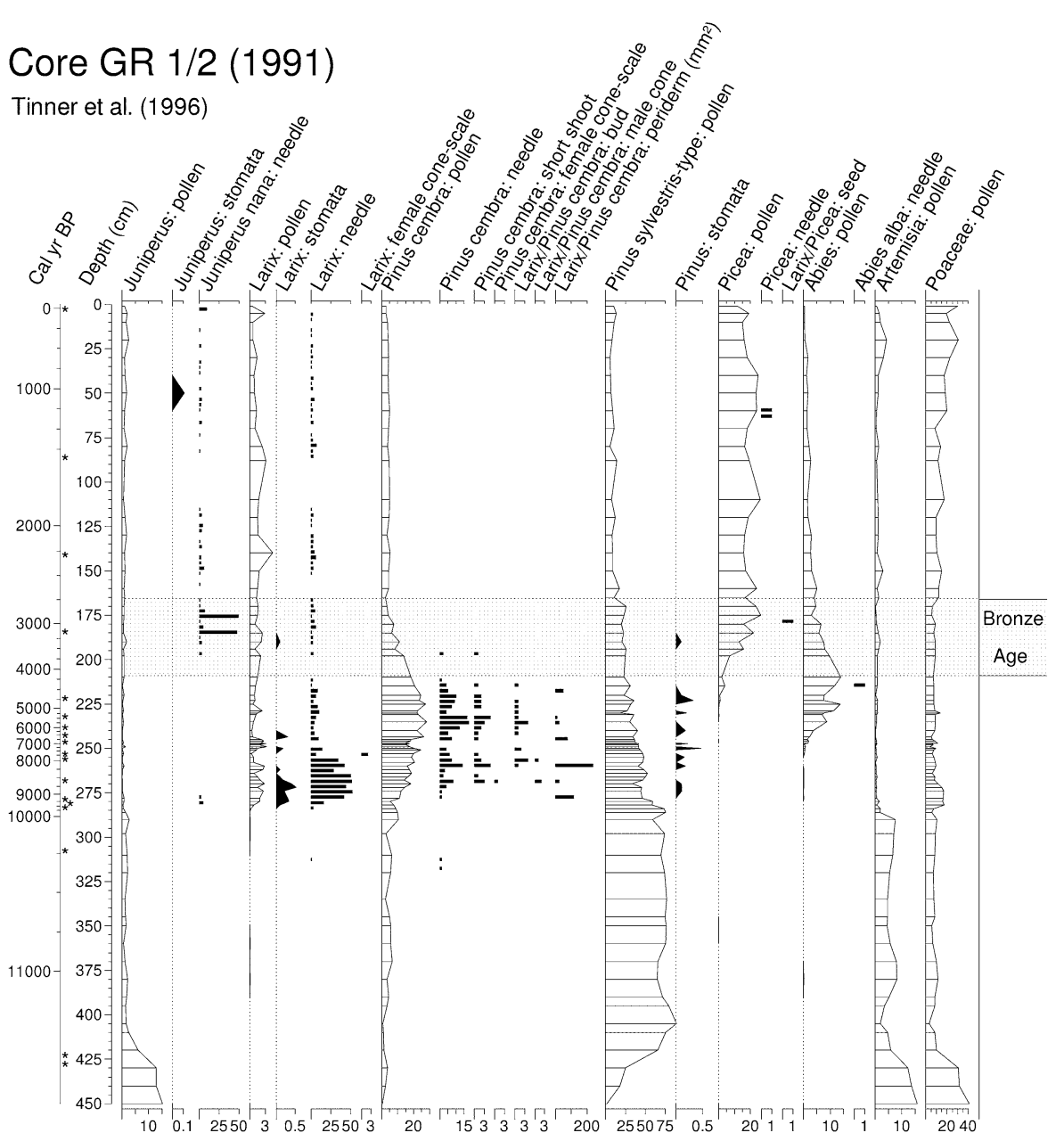

\section{Conifer needles Core 6/7 (1997) \\ Kaltenrieder et al. (2005)}

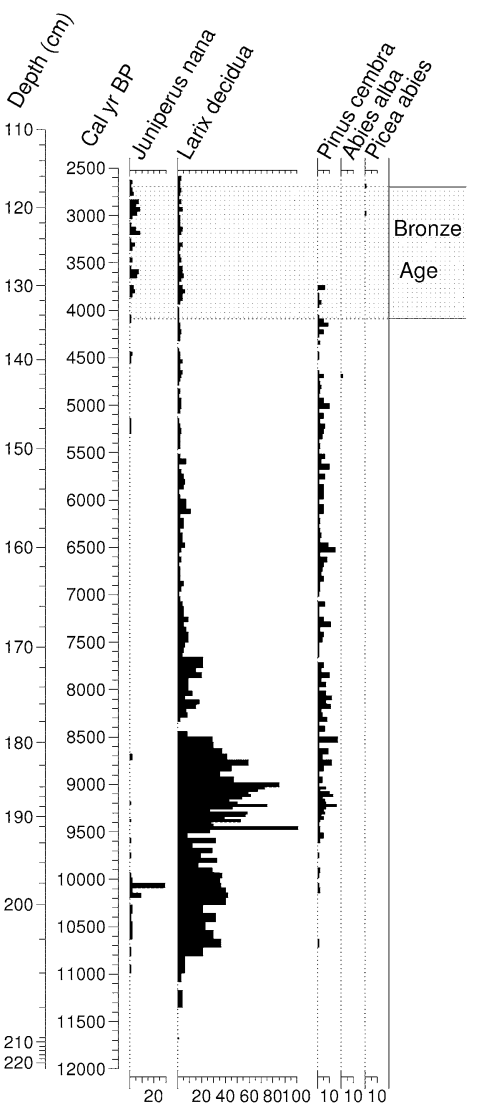
line in the central Alps. Selected taxa only. Left pollen, stomata and macrofossils of conifers in cores GR-1/2; sampling resolution for macrofossils is $5 \mathrm{~cm}$ for the Late-glacial and $3 \mathrm{~cm}$ for the Holocene
Fig. 3 Gouillé Rion at 2,343 m a.s.l., between timberline and tree

(Tinner et al. 1996). Right conifer macrofossils of core $6 / 7$ at a sampling resolution of $0.5 \mathrm{~cm}$; asterisk indicates the position of radiocarbon dates (Kaltenrieder et al. 2005)

\section{Juniperus}

B.P. into more closed forests of L. decidua and P. cembra, mata, and pollen (Fig. 4; Finsinger and Tinner 2007). A. alba probably never played a major role in the forests at the elevation of Lac de Fully, although a single anther (identified by its pollen content) shows the local or nearly local presence of the late-successional conifer around 8,000 cal. B.P. Just as at Gouillé Rion, the local forests at the timberline were disrupted for summer farming during the Bronze Age.

\section{Stomata and pollen across the Alps}

Here the five genera are presented separately. The investigated sites follow an approximate south-north transect.
In the Alps today, J. communis s.l. shows an altitudinal distribution: J. communis s.str. grows up to about $1,600 \mathrm{~m}$ a.s.l., while J. nana (=J. communis ssp. alpina) occurs above 1,600 $\mathrm{m}$ (Oberdorfer 1990). Thus, J. communis s.str. is a species of the colline and montane belts (rarely subalpine), whereas $J$. nana belongs to the subalpine and alpine belts and may occasionally reach 3,000 $\mathrm{m}$ a.s.l. in Valais (Hess et al. 1976). The distinction between $J$. communis and $J$. nana can be made neither on the basis of pollen nor on stomata, but can be made on macrofossils, for example needles and fruits (Figs 3, 4).

During the Late-glacial, Juniperus is often the first conifer to appear, particularly in lowland records, and it 
Fig. 4 Lac de Fully, at 2,135 m a.s.l., below the natural potential tree line, but treeless today. Selected taxa only. Left pollen and stomata as percentages of the pollen sum of terrestrial plants; right: macrofossils as concentrations in $50 \mathrm{~cm}^{3}$; asterisk indicates the position of radiocarbon dates. (Finsinger and Tinner 2007)
Lac de Fully, $2135 \mathrm{~m}$ a.s.l.

Finsinger \& Tinner (2007)

Pollen \& stomata

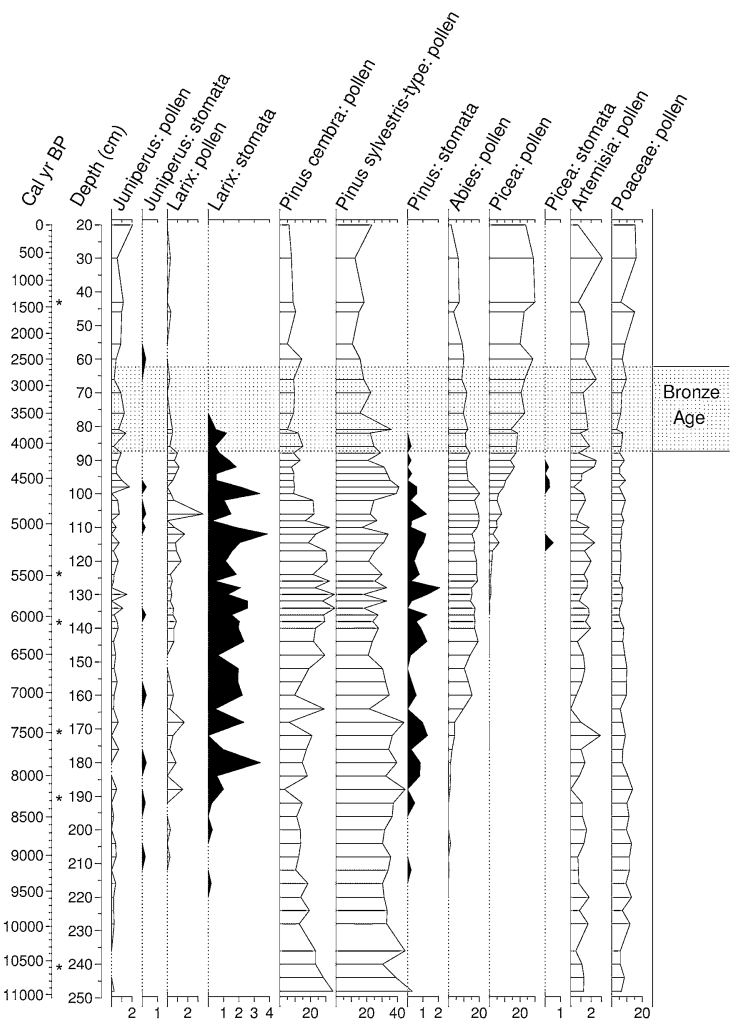

Conifer macrofossils

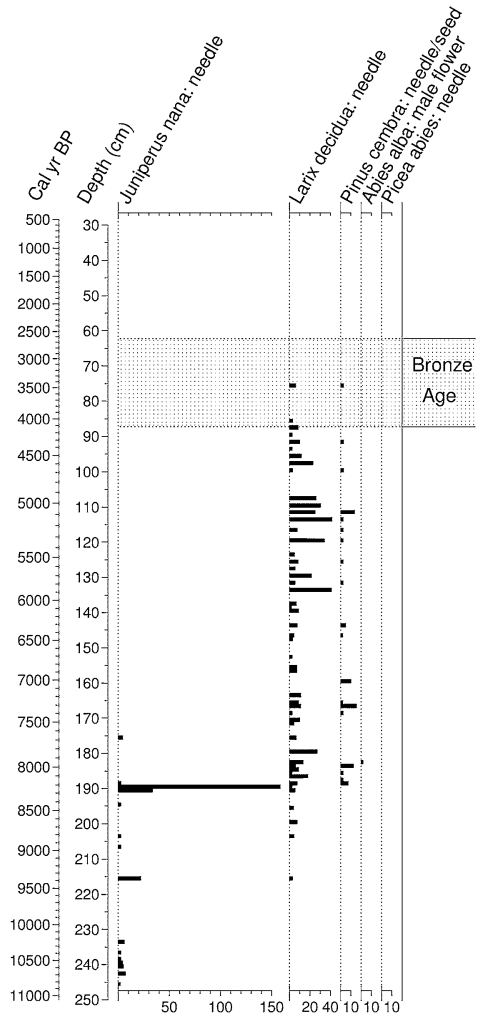

may show one of three different patterns in its early stomata record (Fig. 5):

(1) Some Juniperus pollen appears near the base of the profile but no stomata, then a characteristic increase in pollen accompanied by stomata. In the lowlands south of the Alps Juniperus expands as early as ca. $17,560 \mathrm{cal}$. в.P. in the stomata record, suggesting the establishment of shrublands or open woodlands in response to climate warming at the end of the Late Glacial Maximum (LGM, see Lago di Origlio stomata record). The Oldest Dryas ends abruptly with the onset of the Bølling, starting with the "juniper jump" of Denton et al. (2006). At Le Tronchet and Gerzensee some stomata were found before the marked Juniperus peak. There then follows a decline of both pollen and stomata (Lago di Origlio, Hopschensee, ZeneggenHellelen, Le Tronchet, Gerzensee). In these cases the stomata seem to indicate local presence, whereas the oldest pollen may be from long-distance transport.

(2) Similar, but with a single peak of stomata in the basal sample (Nussbaumer Seen). Reworked material is the probable cause, for this is a widespread phenomenon in peri-alpine records, as testified for example at
Nussbaumer Seen by some Abies pollen which was found in the sandy silt above the till and at other sites on the Swiss Plateau also by Ulmus, pre-Quaternary spores and cysts of dinoflagellates (Ammann 1989).

(3) Both pollen and stomata are found down to the base of the core (Dossaccio-Bormio, Simplon Alter Spittel, Boehnigsee, Eggen ob Blatten, Lai Nair). This implies that the period before the arrival and establishment of juniper was not reached.

During the Holocene, the mass expansion of Juniperus may primarily indicate pastures, as at Gouillé Rion (Kaltenrieder et al. 2005; Tinner and Kaltenrieder 2005).

\section{Pinus}

Pinus is represented by the morphologically distinct pollen of $P$. cembra (Swiss stone-pine, a Haploxylon type) and $P$. sylvestris-type (including $P$. sylvestris and $P$. mugo s.l., which at the elevations of the sites are Diploxylon types). This distinction did not seem to be possible on the basis of stomata, but it may yet be done using stomata-size statistics (Magyari et al. 2012). Pinus is often but not always the second conifer to establish after the ice retreat (or the third 
if Larix plays a role). As Pinus is a strong pollen producer the probability that the pollen has been transported a long distance is high, particularly for $P$. sylvestris. Under the assumption that the (heavy) needles do not get transported so far as pollen, the needle record and the occurrence of stomata make it possible to differentiate between longdistance pollen and local presence. The three species can be distinguished with macrofossil analysis.

In the lowlands south (Fig. 5a) and north (Fig. 5d) of the Alps, Pinus pollen shows either a long, thin "tail" during the Oldest Dryas (Lago di Origlio, Gerzensee) or quite substantial percentages during the oldest part of the Oldest Dryas, when local vegetation was still scarce, before the increase of Artemisia and Poaceae, as at Le Tronchet and Nussbaumer Seen. Stomata of Pinus first occur during the rapid increase of pine pollen (rational limit at Lago di Origlio, Gerzensee, and Nussbaumer Seen) or later (Le Tronchet). The time difference of this local establishment of Pinus south and north of the Alps is large-about 16,000 cal. B.P. at Lago di Origlio (south) and about 13,800 cal. B.P. at Gerzensee (north).

At higher altitudes the distinction between distanttransported and local Pinus pollen is also sometimes possible on the basis of the stomata record (Fig. 5a, b, c): Zeneggen shows first early high Pinus pollen values, then a decrease, followed by an increase concurrent with the first stomata finds; the latter shows the local establishment of pine stands at $1,520 \mathrm{~m}$ a.s.l. during the Allerød. At even higher altitudes Pinus stomata appear in the fossil record only during the early Holocene (Boehnigsee at 2,052 m a.s.l., Hopschensee at 2,217 $\mathrm{m}$ a.s.l.). At some sites the chronology of the oldest sediments is not reliable enough to derive an accurate date for the local establishment of Pinus.

\section{Larix}

Larix provides a strong contrast to Pinus in its production of pollen compared with stomata (Figs 5, 6). Pollen production of Larix is intermediate, but its dispersal very poor (Sjögren et al. 2008a, b); in contrast, production of Larix stomata is higher than in any other conifer genus because of the abundant annual production of the deciduous needles. This difference in needle production may be even larger near the timberline because needle retention in Pinus and Picea under cooler conditions such as at higher altitudes or latitudes was shown to be longer than under warmer conditions (Reich et al. 1996). The Larix records are presented on the same percentage scale for pollen and stomata in Fig. 6 (in contrast to Fig. 5). The strong positive correlation between pollen and stomata is obvious for the high altitude sites in the central Alps: strongest at Simplon Alter Spittel and Hopschensee, somewhat weaker but still clear at Lac de Fully, Zeneggen and Dossaccio, with a nearly continuous stomata record during the early Holocene, but only sporadic finds later at Boehnigsee, Gouillé Rion and Eggen ob Blatten. In the southern Alpine lowlands such as around Lago di Origlio, Larix stomata are rare and restricted to the Late-glacial. Vescovi et al. (2007) present a review of numerous north Italian Late-glacial sites with substantial records of Larix stomata, the oldest at 16,300 cal. B.P. at Lago Piccolo di Avigliana (353 m a.s.l., (Finsinger et al. 2006) and a nearly continuous record after 14,300 cal. B.P. at Palughetto (1,040 m a.s.l.).

\section{Abies}

At Lago di Origlio Tinner et al. (1999) found both the beginning and end of a local presence of Abies stands, a rare case in our transect. Stomata first appear during the rational limit of Abies pollen (8,970 cal. в.P.) and disappear briefly after the pollen decline (4,760 cal. в.P.) (Figs 5a, 7). Tinner et al. (1999) demonstrated that increased fire frequency led to local extinction of this fire-intolerant tree around 5,100 cal. B.P. This is somewhat earlier than at Lago di Ganna $20 \mathrm{~km}$ to the southwest (Fig. 7; Schneider and Tobolski 1985). At Eggen ob Blatten (1,645 m a.s.l.) the first two stomata occur around $8,410 \mathrm{cal}$. B.P. and the last around $4,700 \mathrm{cal}$. в.P. in the middle of a three-step decline in the Abies pollen curve.

All other sites in Fig. 5 show no stomata of Abies except for a single find at Dossaccio (1,730 m a.s.1.), where it occurs together with a small Abies pollen peak. The altitudes of the other sites are either too high or too low for Abies (Fig. 5d), or the climate was too dry as in Valais: some sites show pollen percentages but none show stomata.

\section{Picea}

Picea stomata are absent both at the lowland sites (Lago die Origlio, Le Tronchet, Gerzensee, Nussbaumer Seen) and at the high altitude sites (Gouillé Rion 2,343 m a.s.l.). At intermediate altitudes they occur early at the southeastern site Dossaccio (around 9,400 cal. B.P. at 1,730 m a.s.l.) just before the first of the three steps of increasing pollen. At Simplon Pass early finds of stomata occur with very low pollen percentages at relatively high altitude at Hopschensee (around 5,500 cal. B.P. at 2,217 $\mathrm{m}$ a.s.l.); this is in accordance with the record of Picea needles found by Lang and Tobolski (1985). The stomata at the nearby site Simplon Alter Spittel are somewhat younger (around $3,500 \mathrm{cal}$. в.P. at $1,885 \mathrm{~m}$ a.s.l.). In the inner-alpine valley of Valais, stomata were found at Lac de Fully (ca. $5,100 \mathrm{cal}$. в.P. at $2,135 \mathrm{~m}$ a.s.l., higher than the highest occurrence of closed Picea abies forests today, see Figs. 2, 4, 5b), at Zeneggen (after 4,000 cal. B.P. at 1,520 m a.s.l.) and at Boehnigsee (around 3,200 cal. B.P. at 2,052 m a.s.l.). 
a

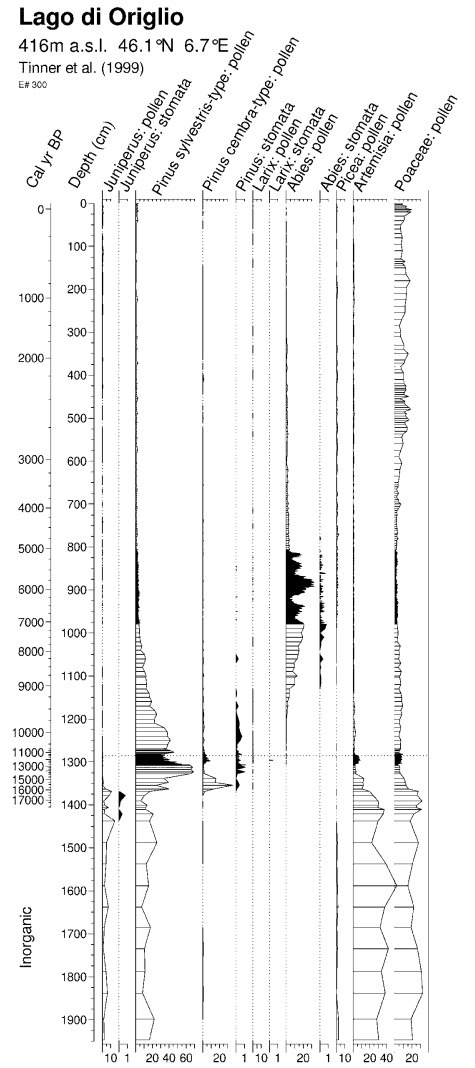

Simplon Alter Spitte

$1885 \mathrm{~m} 46.2^{\circ} \mathrm{N} 8.0^{\circ} \mathrm{E}$

Welten (1982a)

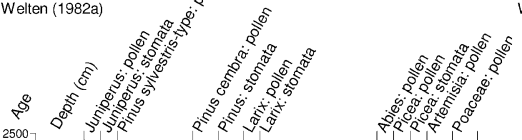

$2217 \mathrm{~m}$ a.s.l. $46.3^{\circ} \mathrm{N} 8.0^{\circ} \mathrm{E}$ 造 Wetten (1982a)
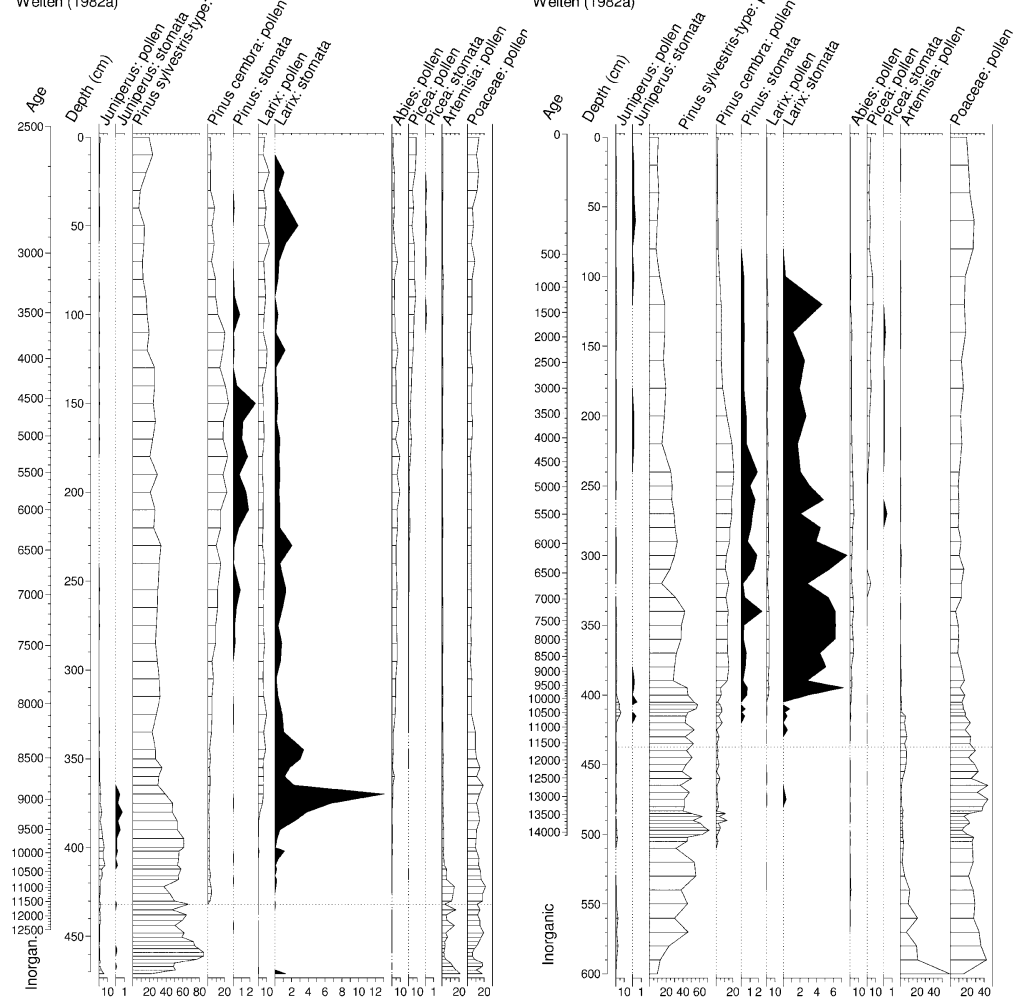

b

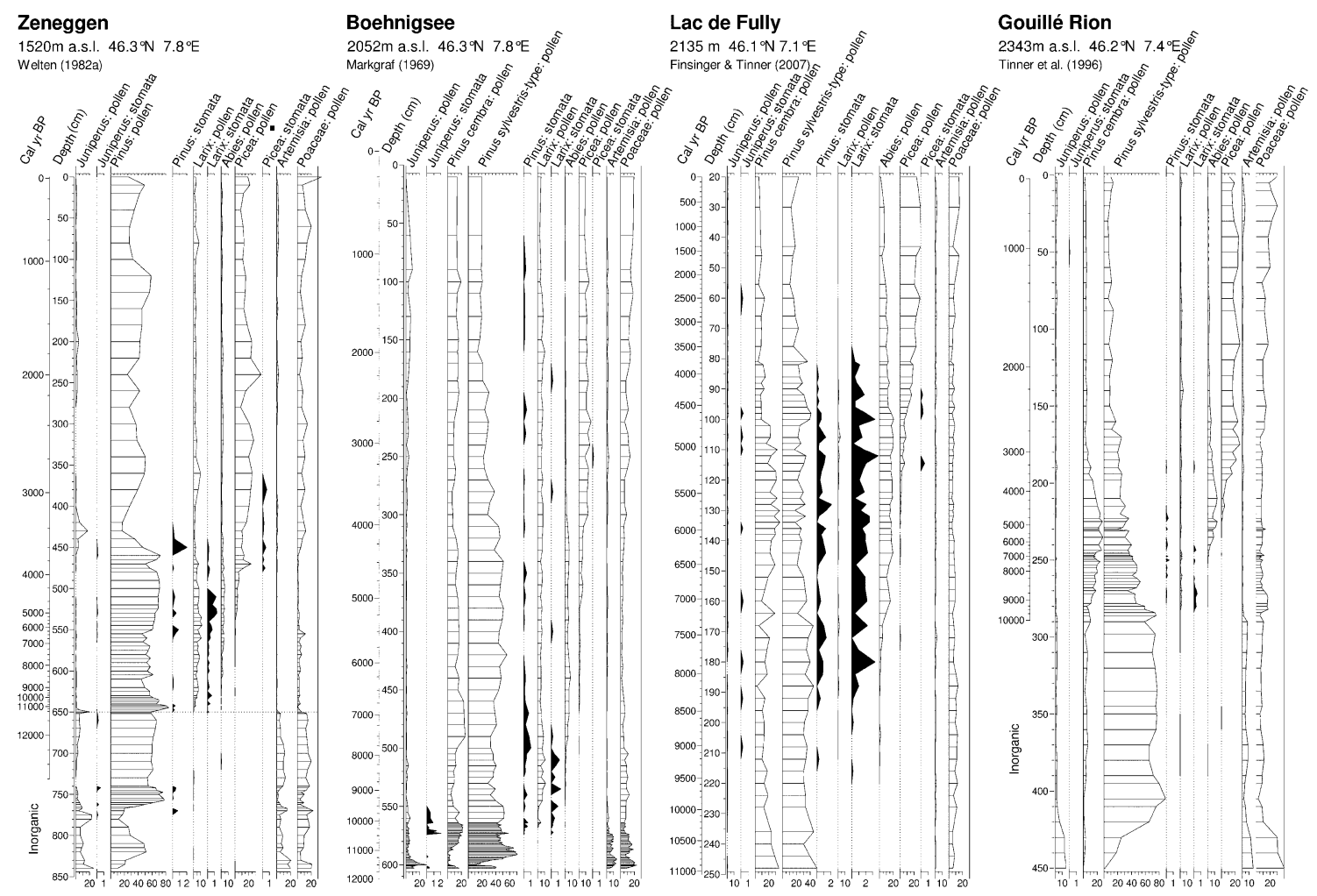

Fig. 5 a-d South-north transect across the Alps with 13 sites providing pollen and stomata records for five gymnosperm genera (Juniperus, Larix, Pinus, Picea, Abies). Pollen and stomata values are percentages of the pollen sum but with different $\mathrm{x}$-axis scales for pollen and stomata 

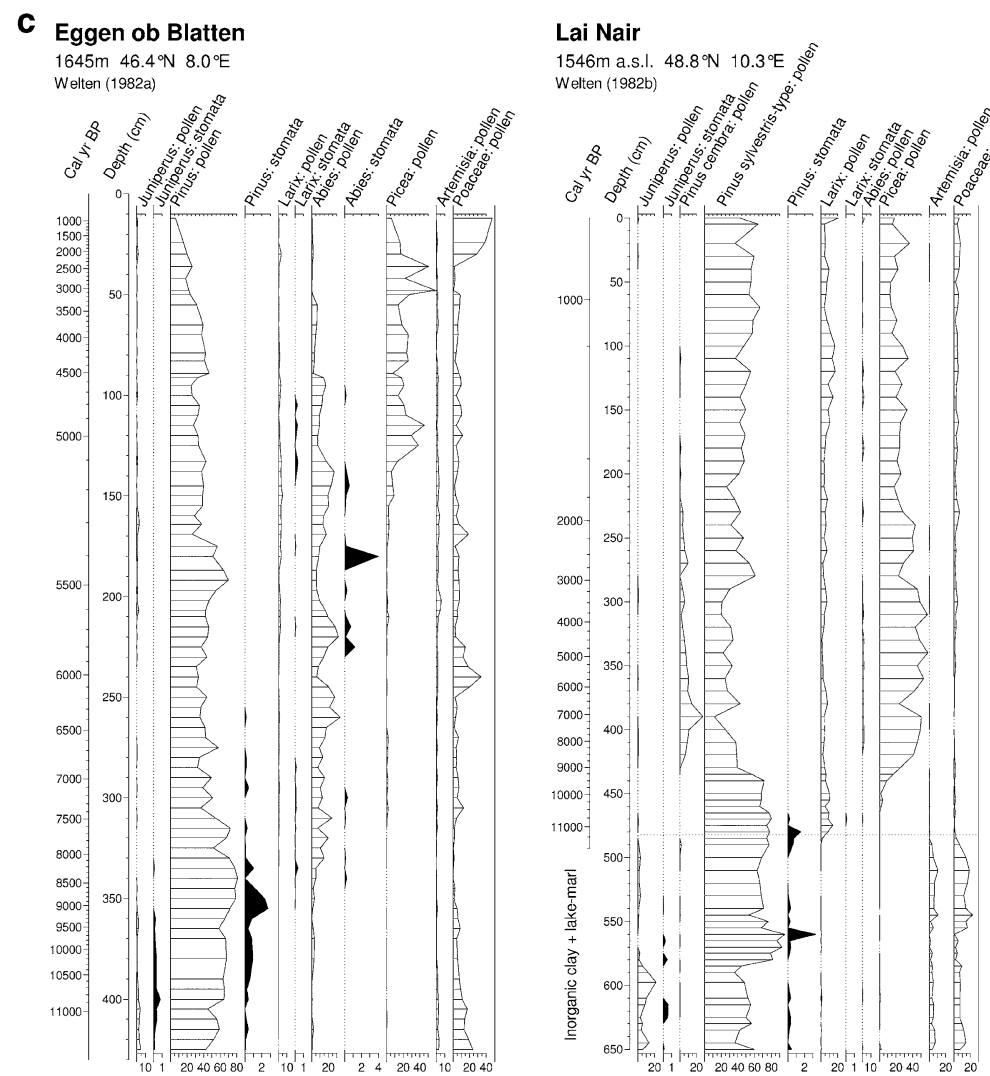

Dossaccio

$1730 \mathrm{~m}$ a.s.l. $46.3^{\circ} \mathrm{N} 10.2^{\circ} \mathrm{E}$ \%

$1546 \mathrm{~m}$ a.s.
Welten (1982b)

Welten (1982b)

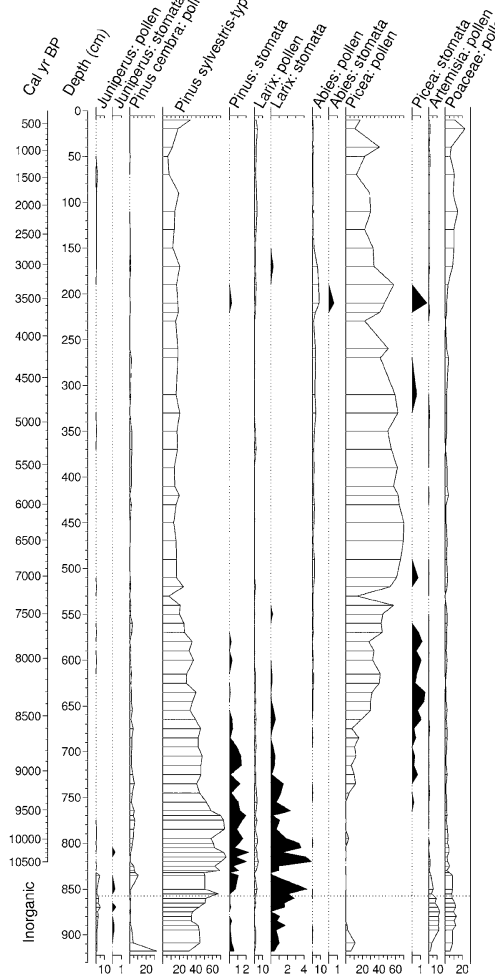

\section{d Le Tronchet}

$715 \mathrm{~m}$ a.s.l. $46.5^{\circ} \mathrm{N} 6.7^{\circ} \mathrm{E}$

Gaillard (1984)

\section{Gerzensee}

$603 \mathrm{~m}$ a.s.l. $46.8^{\circ} \mathrm{N} 7.6^{\circ} \mathrm{E}$

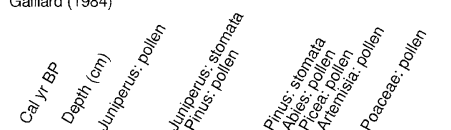
Wick (2000), Ammann et al. (2012)

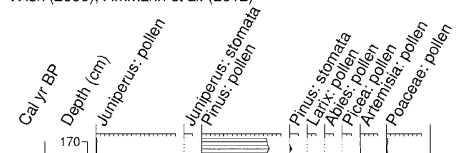

\section{Nussbaumer Seen \\ $434 \mathrm{~m}$ a.s.l. $47.6^{\circ} \mathrm{N} 8.8^{\circ} \mathrm{E}$}

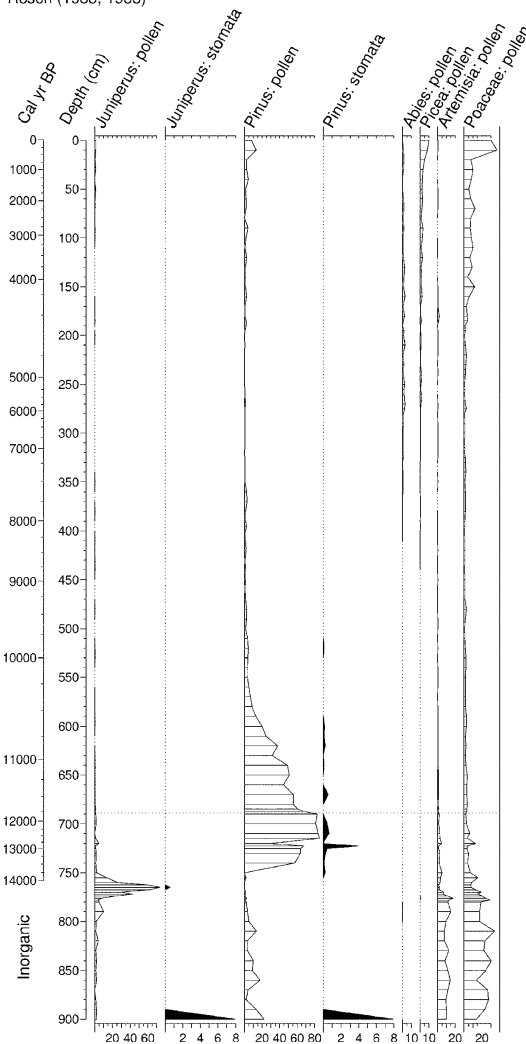

Fig. 5 continued 


\section{Discussion}

Forest establishment traced by stomata

Stomata analysis along with pollen analysis may help to establish the history of the first afforestation after the LGM or the ice retreat. In Figs. 3 and 4 we have included the curves for Artemisia and Poaceae as proxies for the "Lateglacial steppe". On the south-north transect we see that:

- At Lago di Origlio (416 m a.s.1., Tinner et al. 1999) Juniperus stomata records start before the decrease of Artemisia and Poaceae at ca. 17,560 cal. B.P., earlier than the first stomata of Pinus and the first pollen of Larix around 15,500 cal. B.P. (Fig. 5a).

- At Simplon-Alter Spittel (1,885 m a.s.l., Welten 1982a) stomata of Juniperus, Larix and Pinus start before the decline of Artemisia and Poaceae. Welten 1982a already discussed the very early deglaciation of Simplon Pass and the early establishment of trees during the Allerød (13,900-12,800 cal. B.P.) at this south exposed site (Fig. 5a).

- At Hopschensee (Simplon Pass, at 2,217 $\mathrm{m}$ a.s.1., Welten 1982a) the stomata of Larix, then Juniperus and Pinus occur during the decrease of Artemisia and Poaceae at the beginning of the Holocene (beside an early single stoma of Larix) (Fig. 5a).

- Among the five sites in Valais, Zeneggen is the lowest one (1,520 $\mathrm{m}$ a.s.1., Welten 1982a) and two steps of afforestation are visible: during the Allerød, when juniper and pine occur. They disappear during the Younger Dryas and reappear during the earliest Holocene. Thus this site is at the sensitive treeline ecotone during the Younger Dryas (Fig. 5b).

- At Boehnigsee (2,052 m a.s.l., Markgraf 1969) some rare juniper stomata occur near the base of the sequence, but in the early Holocene around 10,400 cal. B.P. frequent and nearly regular occurrences of Juniperus stomata are followed by stomata of pine and larch. The decline of Pinus stomata parallels the decrease of $P$. cembra pollen (7,000-6,000 cal. B.P.), suggesting that this reflects the decline of local $P$. cembra trees and not of the regional $P$. sylvestris-type (Fig. 5b).

- At Lac de Fully (2,135 m a.s.1., Finsinger and Tinner 2007) the early Holocene is not only characterized by longdistance transported Corylus and Ulmus pollen but also by a local decline of D. octopetala leaves and after 9,500 cal. B.P. needles of local L. decidua, a light-demanding species. From about 8,200 cal. B.P. onwards macrofossils of P. cembra were found. Both timberline conifers declined during the Bronze Age and they did not recover (Fig. 5b).

- At Gouillé Rion (2,343 m a.s.l., Tinner et al. 1996; Kaltenrieder et al. 2005; Tinner and Kaltenrieder 2005), an early decline of Artemisia and Poaceae is not accompanied by stomata (older than 11,000 cal. B.P.), but between 10,000 and 9,000 cal. B.P. Artemisia (but not Poaceae) decreases a second time and stomata of Larix and Pinus appear (Fig. 5b).

- In Eggen ob Blatten (1,645 m a.s.l., Welten 1982a) stomata of Juniperus and Pinus are present from the base and during the decrease of Poaceae in the early Holocene (Fig. 5c). Of interest are also the stomata of Abies (present since ca. 8,500 cal. B.P. and abundant ca 5,800-4,700 cal. B.P.). The site of Eggen ob Blatten does not lie in the main valley of Valais with its drycontinental climate, but in a side valley with higher humidity, somewhat comparable to the only major Abies forest today in Derborance (Steiger 2009).

- In Lai Nair (1,546 m a.s.1., Welten 1982b) stomata of Juniperus and Pinus are present during the Late-glacial Interstadial of the Bølling-Allerød and decline during the Younger Dryas, which is marked by higher values of Artemisia and Poaceae. Pollen of Larix is important in the early Holocene, but stomata finds are scarce (Fig. 5c).

- In Dossaccio (1,730 m a.s.1., Welten 1982b) near Bormio in Valtellina (Italy) only the two basal samples are from the Bølling-Allerød Interstadial, then the increase in Artemisia indicates the Younger Dryas. Stomata of Juniperus, Pinus and Larix did not disappear during this cool period. The early Holocene is rich in Larix and Pinus pollen and stomata of both. For Picea the first stoma occurs around 9,400 cal. B.P. just before the first increase of the pollen. With a second and a third increase of Picea pollen, stomata of Larix and Pinus decrease (Fig. 5c).

The three sites on the Swiss Plateau show a very consistent pattern of forest establishment in the Late-glacial (Fig. 5d): Juniperus has a sharp maximum at the onset of the Bølling (14,685 cal. B.P.) and Pinus arrives around 14,000-13,800 cal. B.P. (Gaillard 1984, 1985; Wick 2000; Rösch 1983, 1985; Ammann et al. 2013).

From the records at various altitudes we conclude:

(1) In steppic environments such as that of the early Lateglacial, stomata may help to distinguish between reworked and long-distance pollen. Basal samples containing stomata may indicate reworking (Juniperus and Pinus in Nussbaumer Seen), since needles or stomata are dispersed over much shorter distances than pollen (Birks 2001). Reworking is sometimes also indicated by a record of pre-Quaternary spores.

(2) Shrubland or forest establishment can be inferred from stomata analysis if conifers were important in the vegetation, such as Juniperus and Pinus.

(3) In the altitudinal transect presented here, this first afforestation occurred during the early Late-glacial (Oldest Dryas) at Lago di Origlio, at the beginning of 

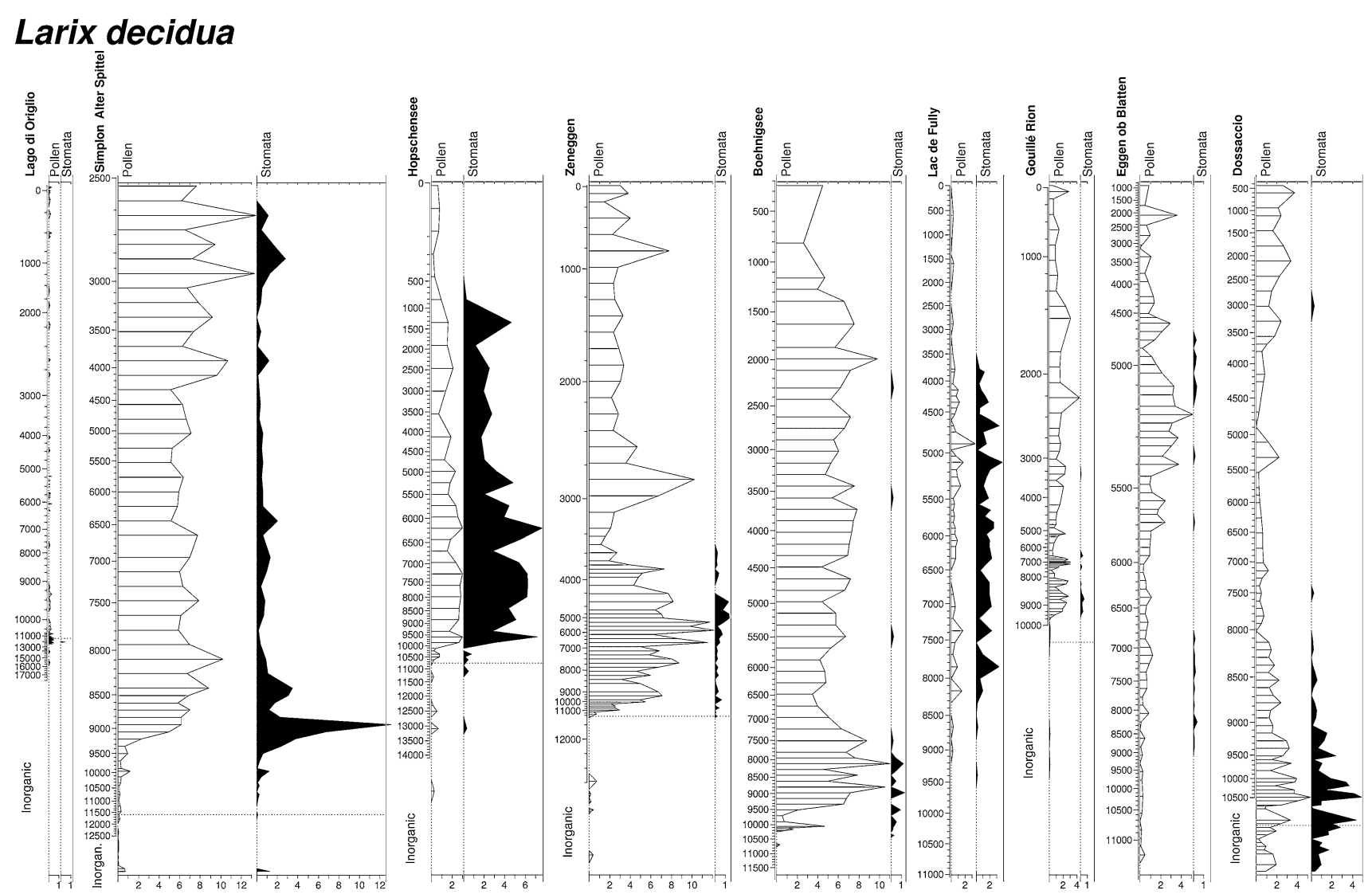

Fig. 6 South-north transect of nine sites from the lowland south of the Alps to the Central Alps for pollen and stomata of Larix, a medium pollen producer but low disperser and strong needle

producer. Pollen and stomata values are percentages of the pollen sum on the same $\mathrm{x}$-axis scales for pollen and stomata

Fig. 7 The relationship of absolute, empirical and rational limits to apparent regional and apparent local presence and to population expansion, respectively. The schemes of Watts (1973) and Birks (1986) are fitted to the stratigraphy of pollen and plant macrofossils of the two wind-pollinated tree taxa Fagus sylvatica and Abies alba at Lago di Ganna

(Schneider and Tobolski 1985) and of pollen and stomata of Abies alba at Lago di Origlio (Tinner et al. 1999). The two taxa are medium pollen producers and good dispersers. Adapted from Lang (1992, 1994)

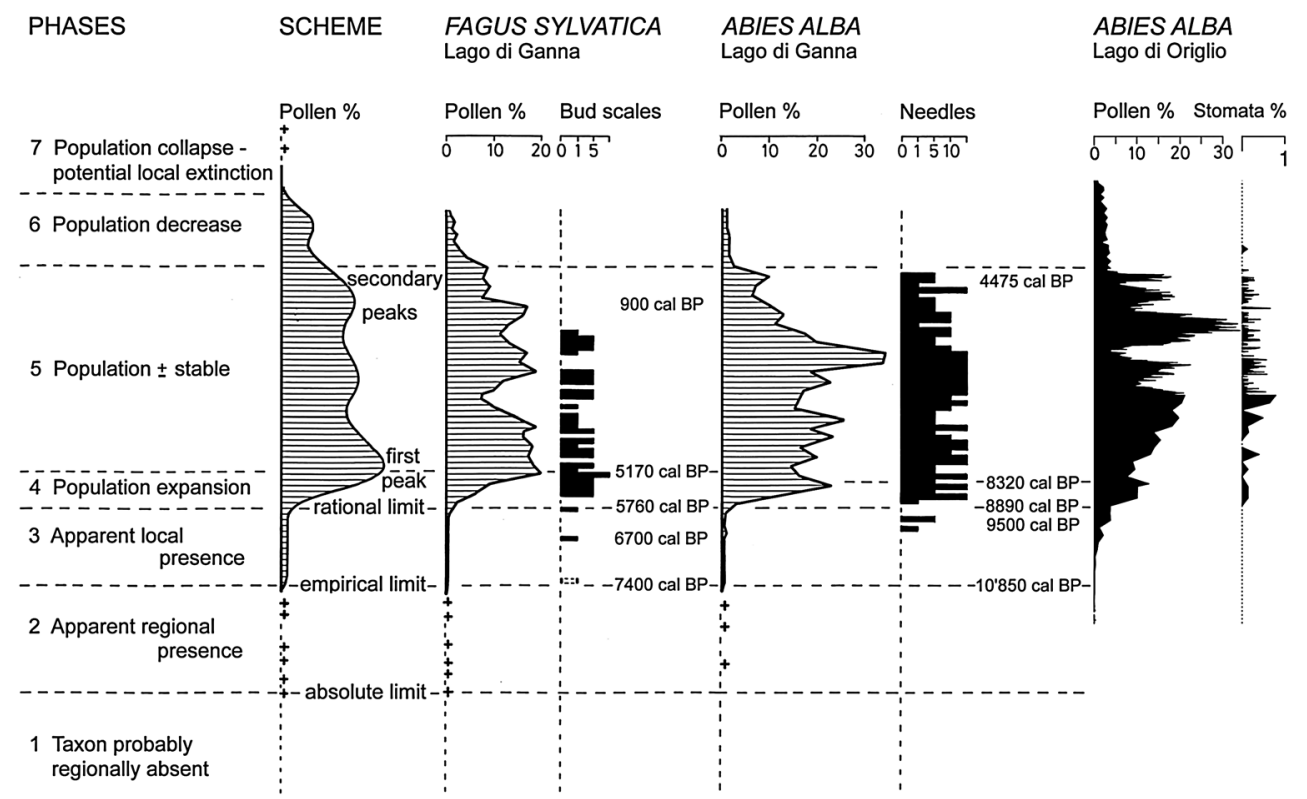

the Bølling on the Swiss Plateau, and in the early Holocene at higher altitudes in the Alps.

(4) Anthropogenic deforestation can be traced with stomata at ecotones formed by conifers as demonstrated at Lac de Fully and Gouillé Rion for the Bronze Age (early transhumance) by the decrease and final disappearance of stomata of Larix and Pinus, if evidence is available for human impact, such 
as pollen of weeds or crops. Grazing may be reflected by finds of stomata of plants that are advantaged by pastoral activities, such as Juniperus at Gouillé Rion.

(5) Finally and perhaps most important, proving the absence of plant taxa remains illusory, and presence is best traced by the analysis of plant macrofossils, often to species level. In the absence of macrofossil records, stomata may be used as a second best tool reaching genus level. The relationship between the earliest stomata found and the traditional pollen limits (absolute-empirical-rational) are summarized in Table 2.

Population decrease and local extinction of conifers recorded at the ending of stomata finds

Stomata may show not only the start of local presence and population growth of conifers but also their decline and their apparent local extinction, corresponding to phases 6 and 7 of Fig. 7. Decline and extinction of taxa may be due to climatic changes, to competition among taxa, and/or to human activities.

(1) Climate and competition: At Lago di Origlio the lightloving taxon Larix declines around 9,000 cal. B.P. with the development of the mixed $A$. alba and deciduous forest and even locally occurring Abies (Tinner et al.
1999). At Gouillé Rion Larix declines when P. cembra becomes abundant. At Dossaccio (1,730 m a.s.l.) the declines of $P$. cembra and $L$. decidua both occur with an increase of Picea in which the stomata record parallels the pollen curve. At Nussbaumer Seen the abundance of Pinus declines strongly with the development of mixed deciduous forest of the early Holocene.

(2) Human impact: tree species that declined were used by prehistoric and historic people for construction and heating (including cheese making) and impeded intense pastoralism: P. cembra and Larix at Lac de Fully, Gouillé Rion, Hopschensee and Simplon AlterSpittel; Abies at Eggen ob Blatten; Picea at Dossaccio. At Lago di Origlio the decline of Abies was shown to correlate with increases of indicators of human activities and higher values of charcoal (Tinner et al. 1999). Around Lac de Fully and Gouillé Rion the Bronze Age people lowered the timberline formed by $P$. cembra and L. decidua for summer farming (Figs. 4, 5b; Finsinger and Tinner 2007; Kaltenrieder et al. 2005; Colombaroli et al. 2010). At Zeneggen Welten (1982a) interpreted increases of Juniperus together with higher values of Poaceae as an indicator of local pastures. Similar patterns are found at Boehnigsee.

Table 2 The five conifer taxa and their stomata record compared to the absolute, empirical and rational limits of the pollen percentage curves

\begin{tabular}{|c|c|c|c|c|c|}
\hline First stomata & Juniperus & Pinus (Haploxylon + Diploxylon) & Larix decidua & Abies alba & Picea abies \\
\hline After rational limit & $\begin{array}{l}\text { Origlio } \\
\text { Zeneggen } \\
\text { Lai Nair } \\
\text { Nussbaumer Seen }\end{array}$ & $\begin{array}{l}\text { Simplon A-S: after high values of } \\
\text { Diploxylon. Continuous stomata with } \\
\text { pollen } \uparrow \text { of Haploxylon. } \\
\text { Boehnigsee; Lac de Fully; Le Tronchet }\end{array}$ & Lai Nair & & Boehnigsee \\
\hline $\begin{array}{l}\text { During the rapid } \\
\text { increase }\end{array}$ & $\begin{array}{l}\text { Hopschensee } \\
\text { Boehnigsee }\end{array}$ & $\begin{array}{l}\text { Lago di Origlio } \\
\text { Hopschensee } \\
\text { Gouillé Rion: during } \uparrow \text { of Haploxylon } \\
\text { Gerzensee }\end{array}$ & $\begin{array}{l}\text { Simplon-A-S } \\
\text { Zeneggen }\end{array}$ & $\begin{array}{l}\text { Lago di Origlio } \\
\text { Eggen ob Blatten } \\
\text { Dossaccio }\end{array}$ & $\begin{array}{l}\text { Zeneggen } \\
\text { Simplon A-S }\end{array}$ \\
\hline $\begin{array}{l}\text { At onset of the } \\
\text { rapid increase }\end{array}$ & & $\begin{array}{l}\text { Zeneggen } \\
\text { Gouillé Rion: during } \downarrow \text { of Diploxylon } \\
\text { Nussbaumer Seen (+ basal peak in clay) }\end{array}$ & Gouillé Rion & & Lac de Fully \\
\hline $\begin{array}{r}\text { Between empirical } \\
\text { and rational limit }\end{array}$ & $\begin{array}{l}\text { Simplon-A-S } \\
\text { Le Tronchet } \\
\text { Gerzensee } \\
\text { Dossaccio }\end{array}$ & Hopschensee & & & $\begin{array}{l}\text { Hopschensee } \\
\text { Dossaccio }\end{array}$ \\
\hline At empirical limit & & & $\begin{array}{l}\text { Lago di Origlio } \\
\text { Hopschensee (+ } \\
\text { basal peak in clay) } \\
\text { Zeneggen } \\
\text { Simplon A-S }\end{array}$ & & \\
\hline $\begin{array}{l}\text { Between absolute } \\
\text { and empirical } \\
\text { limits }\end{array}$ & Lac de Fully & & $\begin{array}{l}\text { Hopschensee } \\
\text { Boehnigsee } \\
\text { Eggen ob Blatten }\end{array}$ & & \\
\hline \multicolumn{6}{|l|}{ At absolute limit } \\
\hline $\begin{array}{l}\text { Before absolute } \\
\text { limit }\end{array}$ & & $\begin{array}{l}\text { Earlier than first Haploxylon-pollen: } \\
\text { Simplon A-S }\end{array}$ & Lac de Fully & & \\
\hline $\begin{array}{l}\text { Level without } \\
\text { stomata not } \\
\text { reached }\end{array}$ & Eggen ob Blatten & $\begin{array}{l}\text { Eggen ob Blatten } \\
\text { Lai Nair } \\
\text { Dossaccio }\end{array}$ & Dossaccio & & \\
\hline
\end{tabular}

Larix behaves differently to all the other coniferous genera in showing stomata with much lower pollen values; this is a result of its high production and shedding of needles, and its medium pollen production and low pollen dispersal 
General considerations about the presence or absence of taxa, and implications for the reconstruction of vegetation history

Macrofossil and stomata records may help to refine the question whether a taxon was locally present at a site. Other important issues, however, are related to the assumption of the absence of taxa. For instance, reconstructing immigrations and migrational routes requires the assumption that the taxon was absent from the site before its first appearance in the fossil record. It is tempting to interpret the beginning of a curve as arrival and an increase as local population expansion of a taxon, as was done by von Post (1924) and later on by Bertsch $(1935,1940)$ and others, at a time when radiocarbon dating was not available to synchronize the pollen records. These assumptions may appear convincing but they require a thorough check.

The assumption has been widely accepted that the (usually exponential) increase of pollen before the first peak (the socalled rational limit) reflects local population expansion. Much more debated is the start of regular pollen occurrence (the so-called empirical limit). Does it reflect the immigration of a taxon or was the taxon already present in the area, though at lower population density? Rudolph (1930) preferred this latter interpretation and assumed that at latest during the early Holocene all taxa had already reached central Europe. In his view, vegetation history (and as a part of it the Central European Ground Succession or "Grundsukzession") reflects (subsequent) expansions of taxa in response to changing climates and environments instead of migrational processes. Later on Welten (1944) supported Rudolph's interpretation. On the basis of spatial distribution densities of trees, Welten (1944) estimated that the presence of 70 individuals of a rare tree species in a forested lake catchment with a radius of 2,300 $\mathrm{m}$ would result in the detection of one pollen grain for every 10,000 grains counted $(0.01 \%)$. Seventy individuals in such a small area around a site are many, if compared to detection uncertainties of ecological field data. Welten's estimate thus indicates that past occupancy might be seriously underestimated when pollen or other even less abundant plant remains are used. The detection frequency $(0.01 \%)$ suggested by Welten corresponds to the sedimentary situation before the beginning of the empirical limit, with one pollen grain in every 20th sample for pollen sums of 500, showing that the arrival or even the initial population establishment of a taxon (with $>50$ individuals) can occur long before the start of the empirical limit in pollen diagrams. Consequently Welten (1944) proposed that the use of pollen values for determining the arrival or local presence of a taxon be avoided and concluded that migrational reconstructions are illusory ("Scheinwanderungen"). Firbas (1949) largely took up the view of Rudolph and Welten, remaining critical of arrival and migration reconstructions. After discussing all relevant dispersal processes that could have induced fast migration rates at or before the start of the Holocene, such as animals, wind, streams or ice floes, he partially rejected the early migrational reconstruction attempts of Bertsch $(1935,1940)$ to emphasize that the assessment of the relevance of migrational processes for the vegetation history of Europe primarily depends on the unequivocal evidence of the arrival time of a taxon. Similarly, Godwin (1956) suggested that $>50 \%$ of the British flora was already established by the end of the Late-glacial. Even for taxa that expanded late in northwestern Europe, such as Fagus sylvatica, he excluded low migrational rates as a cause (p. 208); instead he emphasized the presence of previously established small foci that allowed the taxon to expand quickly once the climatic conditions became sufficiently favourable.

Watts (1973) and later Birks (1986) refined the relationships between the pollen-stratigraphic evidence and the polleninferred arrival and expansion of arboreal plants. Lang (1992) corroborated this approach by including plant macrofossil evidence (Fig. 7). Plant macrofossils (or stomata as a derivative of needles) provide better evidence of local presence than pollen (Birks and Birks 2000), but given the low numbers preserved in the sediment they have significantly less power as evidence of the absence of a taxon at a site. Since it is impossible to prove the spatial absence of a taxon by pollen or macrofossils (Birks and Birks 2003; Hicks 2006; Tinner and Lotter 2006; Giesecke 2013), the reconstruction of the presence and thus immigration of a taxon remains obscure (Seppä 2007). Indeed reconstructing immigration and migrations from pollen or macrofossil evidence disregards the challenges of imperfect detection (see Kérry 2011). We thus suggest that the term immigration should be avoided when dealing with vegetation reconstructions based on pollen-, macrofossil- or stomatainferred vegetation history reconstructions. Instead the terms "apparent local" and "apparent regional" presence may take into account detection uncertainty (Kérry 2011). The terms "apparent local" and "apparent regional" presence have a strong basis in the biostratigraphies. For inferred population dynamics one may use the term "apparent establishment".

On the basis of pollen and macrofossil records seven (dynamic) phases were distinguished and illustrated by Lang (1992, 1994), based on Watts (1973), Birks (1986) and Schneider and Tobolski (1985), shown in Fig. 7 from bottom to top:

(1) No pollen and macrofossils in the sediment record: taxon might be absent.

(2) Occasional pollen grains (after absolute pollen limit), no closed curve, no plant macrofossils: apparent regional presence of the taxon, range close to the site or alternatively, the taxon might be present locally but in low numbers (cryptic presence).

(3) Continuous pollen record (after empirical limit) and/ or first macrofossils: apparent local presence of the taxon, local establishment of population. 
(4) Increase of pollen abundances (after rational limit) to reach a first peak and/or regular occurrence of macrofossils: local population (mass) expansion of a taxon.

(5) Secondary pollen and macrofossil peaks, often smaller than the first peak: population oscillations of the taxon.

(6) Decrease of pollen and/or macrofossil abundance: decline of the population of the taxon.

(7) Disappearance of pollen and macrofossils in the sediment record: population collapse, apparent local extinction.

With regard to pollen, this scheme may apply to windpollinated trees in Europe with average or moderate pollen production and dispersal, such as Abies, Picea, Ulmus, Quercus, Fagus and Carpinus (Fig. 7). In insect-pollinated trees such as Acer and Tilia, or wind and insect pollinated ones such as Castanea or wind-pollinated trees with low pollen production such as Fraxinus excelsior or those with poor dispersal (Larix), single occasional pollen finds (absolute limit) may indicate the apparent local presence of the plant. In strong pollen producers, however, such as Pinus, Betula, Corylus and Alnus, care should be taken when inferring the apparent local presence on the basis of pollen alone. For this latter group the (latest) local presence becomes likely when reaching the rational pollen limit.

Two additional problems need to be kept in mind:

(1) The conventional interpretation that pollen and macrofossil abundances primarily reflect population dynamics, and not productivity changes such as increased flowering or organ production, is supported by recent interdisciplinary studies comparing dynamic modelling outputs, pollen and macrofossil records (Lotter and Kienast 1990; Keller et al. 2002; Heiri et al. 2006; Henne et al. 2011). Productivity changes may indeed occur at annual scales (Hicks 2001, 2007; Sjögren et al. 2008a; Van der Knaap et al. 2010), but are supposed to become relevant at decadal to millennial scales only when the causal factor, such as climatic change, lasts long enough (Fischer et al. 1959; Hicks 2006; Mazier et al. 2012; Sjögren and Kirchhefer 2012).

(2) The second problem when tracking the spatial occurrence, spatial expansion or population expansion on the basis of palaeo-evidence (pollen, stomata, plant macrofossils) is taxonomic resolution. Pollen types may represent species, groups of species, subgenera, genera, or even families. Species-rich taxa such as Quercus robur-type cannot provide details about the history of the individual species involved without macrofossil or leafcuticule evidence (Finsinger et al. 2011), or if the modern spatial species distribution and genetic structure do not deliver additional information. This issue can potentially be resolved by consulting ancient DNA (Gugerli et al. 2013), which may allow reconstruction of vegetation history at subspecies and even population levels.

\section{Conclusions}

Stomata can provide valuable insights into the local apparent presence of conifer taxa, usually at genus level. $P$. sylvestris and $L$. decidua have strongly contrasting records, $P$. sylvestris being a strong pollen producer and L. decidua a strong needle producer. Where present in the sediment, macrofossils can refine the taxonomic resolution of the results and significantly contribute to a better assessment of the local apparent presence of taxa. Together with pollen analysis, which is superior to all other proxies with regard to the large numbers of fossils recorded, stomata and plant macrofossils may contribute to a better assessment of the times of apparent establishment, expansion, decline and extinction of populations.

Based on apparent local presence, inferences of altitudinal or latitudinal fluctuations of tree lines or timberlines may be possible; such fluctuations can be caused either by climatic changes or by human impact.

Extreme care is required when reconstructing the first arrival and thus the immigration or migration of taxa. Currently there is no tool available to track the arrival of the first individual or few individuals at a site. This implies that the reconstruction of immigrations and migrations will remain elusive for a long time. We thus recommend the use of less equivocal terms such as "apparent local" and "apparent regional" presence; for the term "expansion" we need to say if we think of spatial expansion or of the build-up of a population.

Acknowledgments We dedicate this paper to Hilary H. Birks in appreciation of her numerous and inspiring contributions to palaeoecology, of her help, and friendship. We are grateful to Vera Markgraf for submitting her data from Boehnigsee to the pollen data bases, to Peter von Ballmoos for the help with figures and to three anonymous reviewers for their helpful comments.

\section{References}

Ammann B (1989) Late-quaternary palynology at Lobsigenseeregional vegetation history and local lake development. Diss Bot 137:157

Ammann B, Wick L (1993) Analysis of fossil stomata of conifers as indicators of the alpine tree line fluctuations during the Holocene. In: Frenzel B (ed) European palaeoclimate and man. Fischer, Stuttgart, pp 175-185

Ammann B, Van Leeuwen JFN, Van der Knaap WO et al (2013) Vegetation responses to rapid warming and to minor climatic fluctuations during the late-glacial interstadial (GI-1) at Gerzensee (Switzerland). Palaeogeogr Palaeoclimatol Palaeoecol 391:40-59

Barnekow L (1999) Holocene tree-line dynamics and inferred climatic changes in the Abisko area, northern Sweden, based on macrofossil and pollen records. Holocene 9:253-265

Bertsch K (1935) Der deutsche Wald im Wechsel der Zeiten. Heine, Tübingen

Bertsch K (1940) Geschichte des deutschen Waldes. Fischer, Jena

Birks HH (1973) Modern macrofossil assemblages in lake sediments in Minnesota. In: Birks HJB, West RG (eds) Quaternary plant ecology. Blackwell, Oxford, pp 173-189 
Birks HH (1984) Late-quaternary pollen and plant macrofossil stratigraphy at Lochan an Druim, north-west Scotland. In: Haworth E, Lund JWG (eds) Lake sediments and environmental history. University of Leicester Press, Leicester, pp 377-405

Birks HJB (1986) Late-quaternary biotic changes in terrestrial and lacustrine environments, with particular reference to north-west Europe. In: Berglund BE (ed) Handbook of Holocene palaeoecology and palaeohydrology. Wiley, Chichester, pp 3-65

Birks HH (2001) Plant macrofossils. In: Smol JP, Birks HJB, Last WM (eds) Tracking environmental change using lake sediments. Kluwer, Dordrecht, pp 49-74

Birks HH (2007) Plant macrofossils introduction. In: Elias SA (ed) Encyclopedia of quaternary science. Elsevier, Amsterdam, pp 2,266-2,288

Birks HJB, Birks HH (1980) Quaternary palaeoecology. Arnold, London

Birks HH, Birks HJB (2000) Future uses of pollen analysis must include macrofossils. J Biogeogr 27:31-35

Birks HH, Birks HJB (2003) Reconstructing Holocene climates from pollen and plant macrofossils. In: Mackay A, Batterbee R, Birks HJB et al (eds) Global change in the Holocene. Arnold, London, pp 342-357

Birks HH, Mathewes RW (1978) Studies in the vegetation history of Scotland. V. Late devensian and early flandrian pollen and macrofossil stratigraphy at Abernethy forest, Inverness-shire. New Phytol 80:455-484

Birks HH, Vorren K-D, Birks HJB (1996) Holocene tree-lines, dendrochronology and palaeoclimate. Paläoklimaforschung 20:1-18

Bjune AE, Birks HJB, Seppä H (2004) Holocene vegetation and climate history on a continental-oceanic transect in northern Fennoscandia based on pollen and plant macrofossils. Boreas 33:211-223

Brändli UB (1998) Die häufigsten Waldbäume der Schweiz. Ergebnisse aus dem Landesforstinventar 1983-85. Berichte Eidgenöss. Forsch anst. Wald Schnee Landschaft 342

Clayden S, Cwynar L, MacDonald G (1996) Stomate and pollen content of lake sediments from across the tree line on the Taimyr Peninsula, Siberia. Can J Bot 74:1,009-1,015

Clayden S, Cwynar L, MacDonald G et al (1997) Holocene pollen and stomates from a forest-tundra site on the Taimyr Peninsula, Siberia. Arct Alp Res 29:327-333

Colombaroli D, Henne PD, Kaltenrieder P et al (2010) Species responses to fire, climate and human impact at tree line in the Alps as evidenced by palaeo-environmental records and a dynamic simulation model. J Ecol 98:1,346-1,357

Denton GH, Broecker WS, Alley RB (2006) The mystery interval 17.5 to 14.5 kyrs ago. PAGES News $14: 14-16$

Dunwiddie PW (1987) Macrofossil and pollen representation of coniferous trees in modern sediments from Washington. Ecology 68:1-11

Eide W, Birks HH, Bigelow NH et al (2006) Holocene forest development along the Setesdal valley, southern Norway, reconstructed from macrofossils and pollen evidence. Veget Hist Archaeobot 15:65-85

Finsinger W, Tinner W (2007) Pollen and plant macrofossils at Lac de Fully (2135 m a.s.1.): holocene forest dynamics on a highland plateau in the Valais, Switzerland. Holocene 17:1,119-1,127

Finsinger W, Tinner W, van der Knaap WO, Ammann B (2006) The expansion of hazel (Corylus avellana L.) in the Southern Alps: a key for understanding its early holocene history in Europe? Quat Sci Rev 25:612-631

Finsinger W, Lane CS, Van den Brand GJ et al (2011) The lateglacial Quercus expansion in the southern European Alps-rapid vegetation response to a late Allerød climate warming? J Quat Sci 26:694-702

Firbas F (1949) Spät- und nacheiszeitliche Waldgeschichte Mitteleuropas nördlich der Alpen. Fischer, Jena

Fischer F, Schmid-Haas P, Hughes BR (1959) Anzahl und Verteilung der in der Schneedecke angesammelten Fichtensamen. Mitt Eidgenöss Forschanst Wald Schnee Landsch 35:459-479
Froyd C (2005) Fossil stomata, reveal early pine presence in Scotland: implications for postglacial colonization analyses. Ecology 86:579-586

Gaillard M-J (1984) Etude palynologique de l'Evolution Tardi- et Postglaciaire de la Végétation du Moyen-Pays Romand (Suisse) (Diss Bot), vol 77. Cramer, Vaduz

Gaillard M-J (1985) Late-glacial and Holocene environments of some ancient lakes in the Western Swiss Plateau. In: Lang G (ed) Swiss lake and Mire Environments during the last 15000 years (Diss Bot), vol 87. Cramer, Vaduz, pp 273-336

Giesecke T (2013) Changing plant distributions and abundances. In: Elias SA (ed) Encyclopedia of quaternary science, vol 3. Elsevier, Amsterdam, pp 854-860

Giesecke T, Davis B, Brewer S et al (2014) Towards mapping the late quaternary vegetation change of Europe. Veget Hist Archaeobot 23:75-86

Godwin H (1956) The history of the British flora. A factual basis for phytogeography. Cambridge University Press, Cambridge

Gugerli F, Alvarez N, Tinner W (2013) A deep dig-hindsight on Holocene vegetation composition from ancient environmental DNA. Mol Ecol 22:3,433-3,436

Hansen BCS (1995) Conifer stomate analysis as a palaeoecological tool: an example from the Hudson Bay Lowland. Can J Bot 73:244-252

Hansen BCS, MacDonald GM, Moser KA (1996) Identifying the tundra-forest border in the stomata record: an analysis of lake surface samples from the Yellowknife area, Northwest Territories, Canada. Can J Bot 74:796-800

Heiri C, Bugmann H, Tinner W et al (2006) A model-based reconstruction of Holocene treeline dynamics in the Central Swiss Alps. J Ecol 94:206-216

Henne PD, Elkin CM, Reineking B et al (2011) Did soil development limit spruce (Picea abies) expansion in the Central Alps during the Holocene? Testing a palaeobotanical hypothesis with a dynamic landscape model. J Biogeogr 38:933-949

Hess HE, Landolt E, Hirzel R (1976) Flora der Schweiz und angrenzender Gebiete. Birkhäuser, Basel

Hicks S (2001) The use of annual arboreal pollen deposition values for delimiting tree-lines in the landscape and exploring models of pollen dispersal. Rev Palaeobot Palynol 117:1-29

Hicks S (2006) When no pollen does not mean no trees. Veget Hist Archaeobot 15:253-261

Hicks S (2007) Pollen methods and studies: surface samples and trapping. In: Elias SA (ed) Encyclopedia of quaternary science. Elsevier, Amsterdam, pp 2,529-2,535

Jensen C, Kuiper JGJ, Vorren K-D (2002) First post-glacial establishment of forest trees: early Holocene vegetation, mollsuc settlement and climate dynamics in central Troms, North Norway. Boreas 31:285-301

Kaltenrieder P, Tinner W, Ammann B (2005) Zur Langzeitökologie des Lärchen-Arvengürtels in den südlichen Walliser-Alpen. Bot Helv 115:137-154

Keller F, Lischke H, Mathis T et al (2002) Effects of climate, fire, and humans on forest dynamics: forest simulations compared to the palaeological record. Ecol Model 152:109-127

Kérry M (2011) Towards the modelling of true species distributions. J Biogeogr 38:617-618

Lacourse T, Delepine JM, Hodffman EH et al (2012) A 14,000 year vegetation history of a hypermaritime island on the outer Pacific coast of Canada based on fossil pollen, spores and conifer stomata. Quat Res 78:572-582

Lang G (1992) Some aspects of European late- and post-glacial flora history. Acta Bot Fenn 144:1-17

Lang G (1994) Quartäre Vegetationsgeschichte Europas-Methoden und Ergebnisse. Fischer, Jena

Lang G (2005) Seen und Moore des Schwarzwaldes. Andrias 16:1-160 
Lang G, Tobolski K (1985) Hobschensee-late-glacial and Holocene environments of a lake near the timberline. Diss Bot 87:209-228

Leitner R, Gajewski K (2004) Modern and Holocene stomata records of tree-line variations in northwestern Quebec. Can J Bot-Rev Can Bot 82:726-734

Lotter AF, Kienast F (1990) Validation of a forest succession model by means of annually laminated sediments. Geol Surv Finl 14:15-31

MacDonald GM (2001) Conifer stomata. In: Smol JP, Birks HJB, Last WM (eds) Tracking environmental change using lake sediments: terrestrial, algal, and siliceous indicators. Kluwer, Dordrecht, pp 33-47

Magyari EK, Jakab G, Bálint M et al (2012) Rapid vegetation response to Lateglacial and early Holocene climatic fluctuation in the South Carpathian Mountains (Romania). Quat Sci Rev 35:116-130

Markgraf V (1969) Moorkundliche und vegetationsgeschichtliche Untersuchungen an einem Moorsee an der Waldgrenze im Wallis. Bot Jahrb 89:1-63

Mazier F, Nielsen AB, Broström A et al (2012) Signals of tree volume and temperature in a high-resolution record of pollen accumulation rates in northern Finland. J Quat Sci 27:564-574

Oberdorfer E (1990) Pflanzensoziologische Exkursionsflora. Ulmer, Stuttgart

Parshall T (2002) Late Holocene stand-scale invasion by hemlock (Tsuga canadensis) at its western range limit. Ecology 83:1,386-1,398

Paus A, Velle G, Berge J (2011) The Lateglacial and early Holocene vegetation and environment in the Dovre mountains, central Norway, as signalled in two Lateglacial nunatak lakes. Quat Sci Rev 30:1,780-1,796

Pidek IA, Svitavska-Svobodova H, Van der Knaap WO et al (2013) Pollen percentage thresholds of Abies alba based on 13-year annual records of pollen deposition in modified Tauber traps: perspectives of application to fossil situations. Rev Palaeobot Palynol 195:26-36

Pisaric MFJ, Szeicz JM, Karst T et al (2000) Comparison of pollen and conifer stomates as indicators of alpine treeline in northwestern Canadian lake sediments. Can J Bot 78:1,180-1,186

Pisaric MFJ, MacDonald GM, Cwynar LC et al (2001) Modern pollen and conifer stomates from north-central Siberian lake sediments: their use in interpreting Late Quaternary fossil pollen assemblages. Arct Antarct Alp Res 33:19-27

Pisaric MFJ, Holt C, Szeicz JM et al (2003) Holocene treeline dynamics in the mountains of northeastern British Columbia, Canada, inferred from fossil pollen and stomata. Holocene 13:161-173

Reich PB, Oleksyn J, Modrzynski J (1996) Evidence that longer needle retention of spruce and pine populations at high elevations and high latitudes is largely a phenotypic response. Tree Physiol 16:643-647

Rösch M (1983) Geschichte der Nussbaumer Seen/Kt. Thurgau und ihrer Umgebung seit dem Ausgang der letzten Eiszeit aufgrund quartärbotanischer, stratigraphischer und sedimentologischer Untersuchungen. Mitt Thurg Naturf Ges 45:3-110

Rösch M (1985) Nussbaumer Seen-spät- und postglaziale Umweltsveränderungen einer Seengruppe im östlichen schweizer Mittelland. Diss Bot 87:337-379

Rudolph K (1930) Grundzüge der nacheiszeitlichen Waldgeschichte Mitteleuropas. Bh Bot Centrbl 47:111-176

Schneider R, Tobolski K (1985) Lago di Ganna-Late-glacial and Holocene environments of a lake in the southern Alps. Diss Bot 87:229-271

Seppä H (2007) Pollen analysis, principles. In: Elias SA (ed) Encyclopedia of quaternary science. Elsevier, Amsterdam, pp 2,486-2,497

Sjögren P, Kirchhefer AJ (2012) Historical legacy of old-growth pine forest in Dividalen, northern Scandes. Int J Biodivers Sci Ecosyst Serv Manag 8:338-350
Sjögren P, Van der Knaap WO, Huusko A, Van Leeuwen JFN (2008a) Pollen productivity, dispersal, and correction factors for major tree taxa in the Swiss Alps based on pollen-trap results. Rev Palaeobot Palynol 152:200-210

Sjögren P, Van der Knaap WO, Kaplan J, Van Leeuwen JFN, Ammann B (2008b) A pilot study on pollen representation of mountain valley vegetation in the central Alps. Rev Palaeobot Palynol 149:208-218

Steiger P (2009) Wälder der Schweiz-Von Lindengrün zu Lärchengold - Vielfalt der Waldbilder und des Waldes der Schweiz. Ott, Thun

Sweeney CA (2004) A key for the identification of stomata of the native conifers of Scandinavia. Rev Palaeobot Palynol 128:281-290

Tinner W, Kaltenrieder P (2005) Rapid responses of high-mountain vegetation to early Holocene environmental changes in the Swiss Alps. J Ecol 93:936-947

Tinner W, Lotter AF (2006) Holocene expansions of Fagus silvatica and Abies alba in Central Europe: where are we after eight decades of debate? Quat Sci Rev 25:526-549

Tinner W, Theurillat JP (2003) Uppermost limit, extent, and fluctuations of the timberline and treeline ecocline in the Swiss Central Alps during the past 11,500 years. Arct Antarct Alp Res 35:158-169

Tinner W, Ammann B, Germann P (1996) Treeline fluctuations recorded for 12,500 years by soil profiles, pollen, and plant macrofossils in the Central Swiss Alps. Arct Alp Res 28:131-147

Tinner W, Hubschmid P, Wehrli M et al (1999) Long-term forest fire ecology and dynamics in southern Switzerland. J Ecol 87:273-289

Trautmann W (1953) Zur Unterscheidung fossiler Spaltöffungen der mitteleuropäischen Coniferen. Flora 140:523-533

Van der Knaap WO, Van Leeuwen JFN, Svitavska-Svobodova H, Pidek IA, Kvavadze E, Chichinadze M, Giesecke T, Kaszewski BM, Oberli F, Kalnina L, Pardoe HS, Tinner W, Ammann B (2010) Annual pollen traps reveal the complexity of climatic control on pollen productivity in Europe and the Caucasus. Veget Hist Archaeobot 19:285-307

Vescovi E, Ravazzi C, Arpeti E et al (2007) Interactions between climate and vegetation during the Lateglacial period as recorded by lake and mire sediment archives in Northern Italy and Southern Switzerland. Quat Sci Rev 26:1,650-1,669

Von Post L (1924) Some features of the regional history of the forests of southern Sweden in post-arctic time. Geol Fören Stockholm Förhandl 38:384

Watts WA (1973) Rates of change and stability in vegetation in the perspective of long periods of time. In: Birks HJB, West RG (eds) Quaternary plant ecology. Cambridge University Press, Cambridge, pp 195-206

Welten M (1944) Pollenanalytische, stratigraphische und geochronologische Untersuchungen aus dem Faulenseemoos bei Spiez. Veröff Geobot Inst Rübel Zürich 21:1-201

Welten M (1982a) Vegetationsgeschichtliche Untersuchungen in den westlichen Schweizer Alpen: Bern-Wallis. Denkschr Schweiz Naturforsch Ges 95:1-104

Welten M (1982b) Pollenanalytische Untersuchungen zur Vegetationsgeschichte des Schweizerischen Nationalparks. Ergeb wiss Untersuch Schweiz Nationalpark 16:3-43

Wick L (2000) Vegetational response to climatic changes recorded in Swiss Late Glacial lake sediments. Palaeogeogr Palaeoclimatol Palaeoecol 159:231-250

Wick L, Tinner W (1997) Vegetation changes and timberline fluctuations in the Central Alps as indicator of Holocene climatic oscillations. Arct Alp Res 29:445-458

Yu Z (1997) Late Quaternary paleoecology of Thuja and Juniperus (Cupressaceae) at Crawford Lake, Ontario, Canada: pollen, stomata and macrofossils. Rev Palaeobot Palynol 96:241-254 